\title{
Pengembangan Pembelajaran Blended Pada Mata Kuliah Ahara Yoga Semester II di IHDN Denpasar
}

\author{
I Gusti Ayu Agung Manik Wulandari \\ Program Studi Teknologi Pendidikan, Universitas Pendidikan Ganesha \\ dewa.made.adi@undiksha.ac.id \\ I Gde Wawan Sudatha \\ Program Studi Teknologi Pendidikan, Universitas Pendidikan Ganesha \\ dp-parmiti@undiksha.ac.id \\ Alexander Hamonangan Simamora \\ Program Studi Teknologi Pendidikan, Universitas Pendidikan Ganesha \\ aiwiy-sukmana@undiksha.ac.id
}

\author{
A R T I C L E I N F O \\ Article history: \\ 1 Januari 2020 Received in \\ revised form \\ 30 Mei 2020 \\ Accepted 30 Juni 2020 \\ Available online \\ 15 Juli 2020 \\ Kata Kunci: \\ Pembelajaran blended, \\ flipped classroom, ADDIE \\ Keywords: \\ Blended learning, flipped \\ classroom, ADDIE
}

\begin{abstract}
ABSTRAK
Rendahnya hasil belajar mahasiswa disebabkan karena kurangnya media inovatif untuk menfasilitasi mahasiswa dalam belajar, hal inilah yang menjadi penyebab tujuan penelitian ini dilakukan. Penelitian ini bertujuan untuk mendeskripsikan proses pengembangan pembelajaran blended dan validitas rancangan pembelajaran blended. Jenis penelitian ini adalah penelitian desain dan pengembangan dengan model ADDIE yang meliputi lima tahapan yaitu analisis, desain, pengembangan, implementasi danevaluasi. Metode yang digunakan dalam pengumpulan data yaitu pencatatan dokumen, dan kuesioner. Teknik analisis data yang digunakan pada penelitian ini yaitu analisis deskriptif kualitatif dan analisis deskriptif kuantitatif. Rancangan
\end{abstract} pembelajaran blended valid dengan: (a) hasil review ahli mata kuliah dengan kualifikasi sangat baik $(94,6 \%)$, (b) hasil review ahli desain pembelajaran dengan kualifikasi sangat baik (95\%), (c) hasil review ahli E-learning dengan kualifikasi sangat baik (96,5\%), (d) hasil review ahli video pembelajaran dengan kualifikasi sangat baik (98\%), dan (e) hasil uji coba perorangan dengan kualifikasi sangat baik (98,3\%). Jadi, penelitian menunjukan bahwa pembelajaran blended dengan model flipped classroom pada kualifikasi sangat baik.

\begin{abstract}
The low student learning outcomes are due to the lack of innovative media to facilitate students in learning, this was the reason for the purpose of this research. This research aims to describe the process of developing blended learning and the validity of blended learning designs. This type of research was design research and development with ADDIE model which includes five stages namely analysis, design, development, implementation and evaluation. The method used in data collection was document recording and questionnaires. Data analysis techniques used in this research were qualitative descriptive analysis and quantitative descriptive analysis. Blended learning design was valid with: (a) the results of expert expert review with very good qualifications $(94.6 \%)$, (b) the results of expert design learning reviews with very good qualifications $(95 \%)$, (c) the results of expert E-expert reviews learning with very good qualifications $(96.5 \%)$, (d) results of expert video reviews of learning with very good qualifications $(98 \%)$, and (e) results of individual trials with very good qualifications $(98.3 \%)$. So, the research shows that blended learning with flipped classroom models was very good qualifications.
\end{abstract}




\section{PENDAHULUAN}

Ilmu pengetahuan dan teknologi berkembang dengan sangat pesat sehingga membuat perubahan pada segala aspek terutama dalam bidang pendidikan. Pembelajaran saat ini masih dilakukan secara tradisional harus ditransformasikan menjadi modern sebagai prasyarat menghadapi tantangan global (Surpi, 2017). Saat ini, masih banyak pengajar yang menerapkan pembelajaran konvensional. Selain itu, model pembelajaran ceramah masih dominan diterapkan dalam pembelajaran, sehingga akan berdampak terhadap rendahnya hasil belajar mahasiswa. Hal tersebut terjadi di IHDN Denpasar. Berdasarkan hasil wawancara dengan pengampu mata kuliah Ahara Yoga, kendala utama yang ditemukan yaitu belum adanya media inovatif yang mampu menfasilitasi mahasiswa dalam belajar di luar kelas. Selain itu, Jam perkuliahan yang sangat sedikit yakni 2 sks (1 jam 40 menit) perMinggu dengan materi pembelajaran yang sangat banyak juga membuat kesulitan dosen untuk mengatur proses pembelajaran agar materi perkuliahan dapat terselesaikan tepat waktu. Hasil observasi yang dilakukan di IHDN Denpasar, yaitu metode ceramah menjadi dominan dalam proses pembelajaran. Prasarana seperti laboratorium komputer, wifi sudah tersedia tetapi belum dimanfaatkan secara optimal untuk pembelajaran. Dalam sistem penilaian menggunakan penilaian acuan patokan (PAP) mahasiswa mendapatkan rata-rata nilai yaitu 75,3 mendapatkan predikat baik. Berdasarkan analisis dalam konversi tingkat pencapaian dengan skala 5 menyatakan rentangan nilai 75-89 mendapatkan kualifikasi baik, tetapi perlu sedikit revisi, sehingga untuk membantu meningkatkan hasil belajar mahasiswa (Tegeh dan Jampel, 2017).

Berdasarkan masalah tersebut, salah satu solusi yang ditawarkan yaitu dengan menerapkan pembelajaran blended dengan model flipped classroom. Hasil kuesioner yang disebarkan pada mahasiswa semester II Program Studi Yoga dan Kesehatan di IHDN Denpasar, menyatakan bahwa seluruh mahasiswa telah memiliki smartphone dan 84,2\% mahasiswa telah memiliki laptop, 78,9 \% mahasiswa lebih suka mengakses materi pembelajaran melalui digital dan 21,1\% mahasiswa lebih menyukai materi pembelajaran dalam bentuk bahan cetak. Selain itu, $68,4 \%$ mahasiswa lebih mudah menyerap informasi melalui media visual, dan 26,3\% mahasiswa lebih menyukai media audiovisual. Dapat disimpulkan bahwa secara umum mahasiswa lebih menyukai pembelajaran melalui digital (online). Selain itu mahasiswa juga telah memiliki fasilitas yang dapat menunjang pembelajaran online. Berdasarkan hal tersebut dapat disimpulkan bahwa pembelajaran blended dapat diterapkan dalam pembelajaran. Hasil penelitian (Putra, dkk, 2017), menyatakan pembelajaran dengan berbantuan media inovatif mampu meningkatkan kemampuan mengajar guru serta hasil belajar siswa mengalami peningkatan sebesar $60,16 \%$. Selain itu, media pembelajaran inovatif juga dapat memfasilitasi mahasiswa dalam belajar sesuai dengan preferensi gaya belajar masing-masing. Harahap, dkk (2019) dalam penelitian juga menyatakan bahwa pembelajaran blended efektif meningkatkan prestasi dan keterampilan siswa dalam belajar secara secara signifikan. Ceylan dan Ayse (2017) juga menyatakan bahwa lingkungan belajar yang menerapkan blended learning menghasilkan perbedaan signifikan terhadap prestasi belajar siswa sekitar $72 \%$.

Rashty (Chaeruman, 2017) mengklasifikasikan kontinum E-learning kedalam tiga kategori yaitu adjunct, mixed atau blended, fully daring. Blended learning merupakan salah satu bentuk E-learning dengan mengkombinasikan pembelajaran tatap muka dan online. "Pembelajaran blended learning pada dasarnya mengkombinasikan aspek positif dari dua jenis lingkungan belajar yaitu pembelajaran di kelas dan E-learning" Bonk dan Graham 
(Chaeruman, 2017). Kombinasi aspek positif dari strategi pembelajaran sikron dan asinkron akan menciptakan sebuah pengalaman belajar yang menyenangkan sehingga tercapainya tujuan pembelajaran. Hal ini dibuktikan oleh penelitian yang dilakukan oleh Dziuban, dkk (2018) bahwa blended learning merupakan model pembelajaran yang paling disukai oleh pelajar terutama pada pengalaman belajar yang lebih menyenangkan sehingga meningkatkan hasil belajar. Kalantarrashidi, dkk (2015) juga menyatakan bahwa penerapan blended learning dapat membuat kepuasan siswa lebih tinggi jika dibandingkan dengan pembelajaran konvensional dan pembelajaran online saja. Hal ini sejalan dengan penelitian yang dilakukan oleh Kazakoff, dkk (2017) dalam penelitiannya juga menyatakan bahwa pendekatan pembelajaran blended yang memadukan aktivitas pembelajaran online dan digital akan meningkatkan hasil belajar siswa secara signifikan. Penelitian yang dilakukan oleh Albiladi dan Khlood (2019) menyatakan bahwa banyak manfaat yang didapatkan jika menerapkan pembelajaran blended, tidak hanya pada hasil belajar tetapi pada lingkungan belajar yang menyenangkan. Selain itu pembelajaran blended juga dapat mengembangkan ketrampilan penggunaan teknologi pada siswa. Berdasarkan penelitian tersebut, dapat disimpulkan bahwa pembelajaran blended dapat membantu proses pembelajaran menjadi lebih baik, sehingga tujuan pembelajaran tercapai.

Pembelajaran blended memiliki beberapa klasifikasi yaitu: rotation model, flex model, self-blende model, dan enriched-virtual model. Rotation model memiliki beberapa model yaitu station-rotation model, lab-rotation model, flipped classroom model, dan individual-rotation model (Oktaria, dkk, 2018). Model flipped classroom merupakan tipe pembelajaran blended yang dalam penerapannya, peserta mempelajari materi dirumah terlebih dahulu, selanjutnya membahas materi yang telah dipelajari secara mandiri di kelas. Kelebihan dari model flipped classroom yaitu melatih pelajar agar aktif dan mandiri dalam belajar. Bahan ajar yang ditawarkan dalam merealisasikan model flipped classroom ini bervariasi, mulai dari multimedia, video pembelajaran, dan e-handout, sehingga mahasiswa dapat mempelajari materi ajar menyesuaikan dengan gaya belajar dan kecepatan belajar masing-masing. Penelitian yang dilakukan oleh Kurniawati, dkk (2019) menyatakan bahwa, blended learning dengan model flipped classroom dapat meningkatkan hasil belajar.

Chaeruman (2017) menyatakan desain pembelajaran online yang sistematis yang dapat diterapkan pada perguruan tinggi adalah Model Pedati. Model Pedati adalah akronim dari pelajari, dalami, terapkan, dan evaluasi. Model ini merupakan desain pembelajaran online yang sudah diterapkan pada sistem pembelajaran online Indonesia (SPADA). Model Pedati merupakan siklus alur pembelajaran yang akan digunakan dalam sistem pembelajaran blended dengan model flipped classroom. Chaeruman (2017:17) menyatakan Model Pedati terdiri atas lima langkah utama yaitu "merumuskan capaian pembelajaran, memetakan dan mengorganisasikan materi pembelajaran, memilih dan menentukan aktivitas pembelajaran sikron dan asinkron, merancang aktivitas pembelajaran asinkron, merancang aktivitas pembelajaran sikron. Model Pedati digunakan karena menggambarkan suatu prosedur kerja yang sistematis dan logis serta memiliki komponen yang jelas dan berhubungan satu dengan yang lainnya yang akan digunakan dalam pembelajaran online.

Berdasarkan permasalahan di atas, peneliti memandang perlunya model pembelajaran yang dapat membantu mahasiswa dalam belajar, sehingga diperlukan pengembangan pembelajaran blended pada Mata Kuliah Ahara Yoga di IHDN Denpasar. Pembelajaran blended dipilih karena model pembelajaran ini menggabungkan aspek positif 
dari pembelajaran secara langsung dan online, sehingga diharapkan dapat memberikan kenyamanan mahasiswa dalam belajar, kemudahan memahami materi perkuliahan dan dapat belajar secara mandiri.

\section{METODE PENELITIAN}

Penelitian desain dan pengembangan ini dilaksanakan pada tanggal 03 April 2019 sampai 4 Mei 2020. Subjek penelitian ini yaitu: 1 ahli isi mata kuliah, 1 ahli desain pembelajaran, 1 ahli media E-learning, 1 ahli media video pembelajaran, dan 3 orang untuk uji coba perorangan. Penelitian ini menggunakan metode penelitian desain dan pengembangan. Richey, dkk (2015) menyatakan design and development research merupakan studi sistematis proses mendesain, mengembangkan, dan evaluasi dengan tujuan menciptakan produk dan alat pengajaran. Penelitian desain dan pengembangan ini menekankan proses desan pembelajaran sebagai pemecahan masalah ilmiah. Dalam mencapai tujuan, penelitian desain dan pengembangan melalui dua kategori yaitu penelitian tentang produk, dan penelitian tentang model serta desain pengembangan Richey, dkk (2015) Dapat disimpulkan bahwa penelitian desain dan pengembangan merupakan penelitian sistematis yang meliputi desain, pengembangan, evaluasi untuk menciptakan atau menyempurnakan sebuah produk yang menekankan proses desain pembelajaran sebagai pemecahan ilmiah.

Prosedur penelitian desain dan pengembangan ini mengacu pada model ADDIE. Tegeh dan Jampel (2017:79) menyatakan tahapan model ADDIE terdiri atas lima tahapan yaitu: "analisis (analyze), desain (design), pengembangan (development), implementasi (implementation), dan evaluasi (evaluation)". Pemilihan model ini didasari atas pertimbangan karena model ini memiliki tahapan yang sistematis dan mudah dipahami dan berpijak pada landasan teoritis desain pembelajaran.

Pengumpulan data pada penelitian ini yaitu menggunakan metode pencatatan dokumen dan kuesioner. Metode pencatatan dokumen merupakan cara memperoleh data dengan mengumpulkan dokumen dan mencatat secara sistematis (Agung, 2017). Metode pencatatan dokumen dilakukan dengan membuat laporan tahap yang telah dilakukan dalam mengembangan E-learning. Dokumen yang dikumpulkan adalah rekapan nilai mahasiswa mata kuliah Ahara Yoga, silabus, sumber belajar yang dipakai dalam proses pembelajaran. Metode kuesioner merupakan cara memperoleh data dengan mengirim daftar pertanyaan dan dijawab secara tertulis (Agung, 2017). Metode kuesioner digunakan untuk mengetahui karakteristik mahasiswa dan fasilitas yang dimiliki mahasiswa dalam menunjang pembelajaran blended. Metode ini juga digunakan untuk mengukur kelayakan produk yang dikembangkan dari ahli isi mata kuliah, ahli desain pembelajaran, ahli media pembelajaran, dan uji coba perorangan.

Instrumen yang digunakan dalam mengumpulkan data penelitian yaitu: lembar pencatatan dokumen dan lembar kuesioner. Lembar pencatatan dokumen mengenai laporan perkembangan produk yang digunakan dalam mengumpulkan data desain pengembangan produk dari tahap analisis hingga evaluasi. Lembar kuesioner digunakan untuk mengumpulkan data mengenai karakteristik mahasiswa, fasilitas yang dimiliki mahasiswa, review dari ahli isi mata kuliah, ahli desain, media pembelajaran, dan uji coba perorangan. Adapun kisi-kisi mata kuliah, ahli desain, media pembelajaran, dan uji coba perorangan dijabarkan pada tabel 1, 2, 3, dan tabel 4 . 
Tabel 1. Kisi-kisi Instrumen Ahli Desain Pembelajaran

\begin{tabular}{|c|c|c|c|c|}
\hline No & Aspek & Indikator & No. Butir & $\begin{array}{c}\text { Jumlah } \\
\text { Butir }\end{array}$ \\
\hline 1 & Kurikulum & $\begin{array}{l}\text { a. Identitas } \\
\text { b. Kejelasan Informasi } \\
\text { c. Kompetensi yang ingin dicapai }\end{array}$ & $1,2,3,4$ & 4 \\
\hline 2 & Metode & $\begin{array}{ll}\text { a. Kelengkapan Media } \\
\text { b. Kejelasan Petunjuk Belajar } \\
\text { c. Kejelasan Rancangan Pembelajaran } \\
\text { d. Ketersediaan Dukungan Bahan Ajar } \\
\text { e. Ketersediaan Pembelajaran Tatap } \\
\text { Muka dan Online }\end{array}$ & $\begin{array}{l}5,6,7,8,9 \\
10,11,12 \\
13\end{array}$ & 9 \\
\hline 3 & Evaluasi & $\begin{array}{ll}\text { a. Relensi soal } \\
\text { b. } & \text { Ketersediaan evaluasi pembelajaran }\end{array}$ & $\begin{array}{l}14,15,16, \\
17\end{array}$ & 4 \\
\hline & \multicolumn{3}{|c|}{ Jumlah } & 17 \\
\hline
\end{tabular}

(Sumber: Prawiladilaga, 2015)

Tabel 2. Kisi-kisi Instrumen Ahli Isi Mata Kuliah

\begin{tabular}{|c|c|c|c|c|}
\hline No & Aspek & Indikator & No. Butir & $\begin{array}{c}\text { Jumlah } \\
\text { Butir }\end{array}$ \\
\hline 1 & Kurikulum & $\begin{array}{l}\text { a. Identitas } \\
\text { b. Capaian Pembelajaran } \\
\text { c. Tujuan embelajaran }\end{array}$ & $1,2,3$ & 3 \\
\hline 2 & Materi & $\begin{array}{l}\text { a. Ketepatan isi materi } \\
\text { b. Sistematika materi } \\
\text { c. Tingkat kemudahan dan kedalaman } \\
\text { materi }\end{array}$ & $\begin{array}{l}4,5,6,7,8 \\
9,10,11\end{array}$ & 8 \\
\hline 3 & Bahasa & $\begin{array}{l}\text { a. Kejelasan informasi } \\
\text { b. Penggunaan bahasa } \\
\text { c. Keterbacaan }\end{array}$ & $12,13,14$ & 3 \\
\hline 3 & Evaluasi & $\begin{array}{l}\text { a. Tingkat kesulitan soal } \\
\text { b. Kejelasan rumusan soal }\end{array}$ & $15,16,17$ & 3 \\
\hline & \multicolumn{3}{|c|}{ Jumlan } & 17 \\
\hline
\end{tabular}

Tabel 3. Kisi-kisi Instrumen Ahli Isi Video Pembelajaran

\begin{tabular}{|c|c|c|c|c|}
\hline No & Aspek & Indikator & No. Butir & $\begin{array}{c}\text { Jumlah } \\
\text { Butir }\end{array}$ \\
\hline 1 & Isi & $\begin{array}{l}\text { a. Tingkat kemudahan serta } \\
\text { pemahaman materi } \\
\text { b. Ketepatan isi materi }\end{array}$ & $1,2,3,4$ & 4 \\
\hline 2 & $\begin{array}{l}\text { Penyajian } \\
\text { Video }\end{array}$ & $\begin{array}{l}\text { a. Kejelasan Informasi } \\
\text { b. Penggunaan Bahasa } \\
\text { c. Keterbacaan }\end{array}$ & $\begin{array}{l}5,6,7,8,9, \\
10,11\end{array}$ & 8 \\
\hline & & Jumlah & & 12 \\
\hline
\end{tabular}


Tabel 4. Kisi-kisi Instrumen Ahli Media (E-learning)

\begin{tabular}{|c|c|c|c|c|}
\hline No & Aspek & Indikator & No. Butir & $\begin{array}{c}\text { Jumlah } \\
\text { Butir }\end{array}$ \\
\hline 1 & Tampilan & $\begin{array}{l}\text { a. Layout } \\
\text { b. Kualitas video } \\
\text { c. Kejelasan gambar } \\
\text { d. Ketepatan jenis dan ukuran } \\
\text { huruf/angka } \\
\text { e. Konsistensi navigasi }\end{array}$ & $\begin{array}{l}1,2,3,4,5 \\
6,7,8,9,10 \\
11\end{array}$ & 11 \\
\hline 2 & Interaktifitas & $\begin{array}{l}\text { a. Kemudahan pengoperasian } \\
\text { b. Ketersediaan konten materi }\end{array}$ & $\begin{array}{l}13,14,15, \\
16\end{array}$ & 4 \\
\hline 3 & Kemanfaatan & $\begin{array}{l}\text { a. Kejelasan informasi } \\
\text { b. Penggunaan bahasa } \\
\text { c. Keterbacaan }\end{array}$ & $17,18,19$ & 3 \\
\hline \multicolumn{4}{|c|}{ Jumlah } & 19 \\
\hline
\end{tabular}

Tabel 5. Kisi-kisi Instrumen Ahli Media (Video Pembelajaran)

\begin{tabular}{llllc}
\hline No & Aspek & \multicolumn{1}{c}{ Indikator } & No. Butir & $\begin{array}{c}\text { Jumlah } \\
\text { Butir }\end{array}$ \\
\hline 1 & Gambar & $\begin{array}{l}\text { a. Kemenarikan } \\
\text { b. Kesesuaian gambar }\end{array}$ & 1,2 & 2 \\
2 & Suara & $\begin{array}{l}\text { a. Kejelasan suara presenter } \\
\text { b. Backsound }\end{array}$ & $7,8,9,10$ & 4 \\
& & Kesesuaian penyajian video & $3,4,5,6,11$, & 8 \\
3 & $\begin{array}{l}\text { Penyajian } \\
\text { Video }\end{array}$ & \multicolumn{2}{c}{12,13} & \\
\hline & & Jumlah & (Sumber: Mahadewi, 2012)
\end{tabular}

Selanjutnya instrumen dinilai oleh pakar (judges) yang memiliki keahlian variabel yang akan diteliti. Setelah di-review oleh pakar (judges) kemudian diperoleh validitas isi yang diisyaratkan dan dianalisis dengan rumus Gregoy dengan mekanisme yaitu: "pakar yang melakukan penilaian instrumen mengklarifikasi butir instrumen, hasil penilaian pakar ditabulasi dalam bentuk matrik, dibuat tabulasi silang, dan dilakukan perhitungan validitas isi" (Retnawati, 2016:32).

Metode analisis data yang digunakan pada penelitian desain dan pengembangan ini yaitu metode analisis deskriptif kualitatif, dan metode deskriptif kuantitatif. Agung (2017:118) menyatakan metode analisis deskriptif kualitatif merupakan "cara mengolah data secara sistematis dalam bentuk kalimat atau kata-kata, sehingga memperoleh kesimpulan umum". Teknik ini digunakan untuk mengolah data hasil uji coba ahli mata kuliah, ahli desain pembelajaran, ahli media pembelajaran, dan uji coba perorangan. Informasi yang didapatkan, dikelompokkan berdasarkan masukan, kritik, tanggapan, dan saran yang terdapat pada kuesioner. Hasil analisis digunakan untuk merevisi produk yang dikembangkan. Metode analisis deskriptif kuantitatif merupakan "cara pengolahan data yang dilakukan secara sistematis dalam bentuk angka hingga memperoleh kesimpulan 
umum”. Dalam memberikan makna dan pengambilan keputusan mengenai pembelajaran blended digunakan acuan sebagai berikut pada tabel 1 .

Tabel 6. Konversi Tingkat Pencapaian dengan Skala 5

\begin{tabular}{ccc}
\hline Tingkat & Kualifikasi & Keterangan \\
Pencapaian & Sangat baik & Tidak perlu direvisi \\
$90 \%-100 \%$ & Baik & Sedikit direvisi \\
$75 \%-89 \%$ & Cukup & Direvisi secukupnya \\
$65 \%-74 \%$ & Kurang & Banyak hal yang direvisi \\
$55 \%-64 \%$ & Sangat Kurang & Diulangi membuat produk \\
$0-54 \%$ & & (Sumb
\end{tabular}

(Sumber: :Tegeh dan Jampel, 2017:223)

\section{HASIL DAN PEMBAHASAN}

\section{HASIL}

Hasil penelitian ini akan dibahas dua hal pokol yaitu: mendeskripsikan rancang bangun pembelajaran blended, dan mendeskripsikan hasil validitas pengembangan pembelajaran blended.

Rancang bangun pembelajaran blended menggunakan model pengembangan ADDIE. Pengembangan blended dimulai pada tahap analisis. Hasil kegiatan analisis yang telah dilakukan yaitu: (1) analisis mata kuliah, seperti: menetapkan indikator dan isi bidang studi, analisis tujuan dan karakteristik isi bidang studi, dan menetapkan strategi pengelolaan pembelajaran, (2) analisis karakteristik mahasiswa, hasil yang didapatkan adalah $64,8 \%$ mahasiswa lebih mudah menyerap informasi melalui media visual dan 26,3\% mahasiswa lebih mudah menyerap informasi melalui media audiovisual, sehingga bahan ajar yang cocok untuk dikembangkan yaitu video pembelajaran dan e-handout, (3) dan analisis lingkungan serta fasilitas yang dimiliki, didapatkan bahwa seluruh mahasiswa telah memiliki smartphone dan $84,2 \%$ mahasiswa telah memiliki laptop, akses wifi di kampus yang memadai sehingga dapat mendukung pembelajaran blended.

Tahap kedua adalah desain. Pada tahap ini dilakukan pembuatan flowchart dan storyboard E-learning dan video pembelajaran, serta menyusun kegiatan pembelajaran blended dengan Model Pedati. Flowchart digunakan sebagai gambaran alur kerja $E$ learning dan video pembelajaran yang akan dikembangkan. Storyboard digunakan sebagai alur dari gagasan pengembangan E-learning dan video pembelajaran.

Tahap ketiga adalah pengembangan. Pada tahap ini kegiatan yang dilakukan yaitu: (1) mengembangkan E-learning. Pada tahap ini dimulai dari instalasi Moodle pada akun hosting, kemudian mengatur hak akses pengguna, (2) mengembangkan video pembelajaran dan $e$-handout. Proses pengembangan video dilakukan dengan pengumpulan materi ajar, kemudian take video dan tahap terakhir yaitu eding video. Proses pengembangan $e$-handout dilakukan dengan pengumpulan sumber referensi, pengetikan, dan menyusunan materi, (3) mempersiapkan kuesioner tentang kelayakan pengembangan pembelajaran blended, (3) mengembangan desain pembelajaran blended yang berpedoman pada Model Pedati, dan (4) Mengembangkan butir-butir soal sebagai instrumen hasil belajar.

Tahap keempat yaitu implementasi. Pada tahap ini kegiatan yang dilakukan meliputi: (1) uji validasi pembelajaran blended berdasarkan aspek isi mata kuliah Ahara Yoga oleh ahli isi mata kuliah Ahara Yoga, (2) uji validasi pembelajaran blended berdasarkan aspek 
desain oleh ahli desain pembelajaran, (3) uji validasi E-learning berdasarkan aspek media oleh ahli media E-learning, (4) uji validasi video pembelajaran berdasarkan aspek media oleh ahli video pembelajaran, dan (5) uji coba perorangan, yang bertujuan untuk mengetahui kelayakan dan kualitas pembelajaran blended dengan model flipped classroom yang dikembangkan.

Tahap terakhir yaitu evaluasi. Tahap ini merupakan tahap terakhir melakukan evaluasi data yang telah terkumpul pada tahap implementasi. Evaluasi berupa formatif. Evaluasi formatif bertujuan untuk menilai produk yang telah dikembangkan mencangkup validitas ahli, dan uji coba perorangan. Berdasarkan tahapan tersebut, maka pembelajaran blended dengan model flipped classroom berhasil dikembangkan dengan model ADDIE.

Uji validitas pembelajaran blended bertujuan untuk menguji tingkat kelayakan pembelajaran blended dengan model flipped classroom. Instrumen pengembangan pembelajaran blended ini berupa kuesioner yang sebelumnya sudah dipersiapkan yang bertujuan untuk mengetahui validitas produk. Instrumen tersebut terlebih dahulu diuji validitas butirnya oleh orang judges yang berkompeten. Adapun hasil validasi instrumen yang telah diuji, dipaparkan pada tabel 7 .

Tabel 7. Hasil dari Uji Validitas Instrumen

\begin{tabular}{lcl}
\hline \multicolumn{1}{c}{ Jenis Validitas } & Hasil & \multicolumn{1}{c}{ Kualifikasi } \\
\hline Validitas Isi & 1 & Sangat Tinggi \\
Validitas Desain & 1 & Sangat Tinggi \\
\hline Validitas Media & 1 & Sangat Tinggi \\
\hline
\end{tabular}

Hasil dari validitas instrumen isi mata kuliah oleh judges mendapatkan nilai 1, sehingga termasuk dalam kriteria validitas sangat tinggi. Hasil dari validitas instrumen desain pembelajaran mendapatkan nilai 1 sehingga termasuk dalam kriteria validitas sangat tinggi, dan hasil validitas media pembelajaran blended juga mendapatkan kualifikasi sangat tinggi. Setelah dilakukan uji validitas instrumen, kemudian dilanjutkan dengan penilaian dari para ahli (ahli isi mata kuliah, ahli desain pembelajaran, ahli media E-learning dan video pembelajaran) terhadap produk yang dikembangkan. Adapun hasil tersebut secara rinci dipaparkan pada tabel 8 .

Tabel 8. Hasil Uji Validitas Produk

\begin{tabular}{clcl}
\hline No & \multicolumn{1}{c}{ Subjek Uji Coba } & Hasil Validitas (\%) & Keterangan \\
\hline 1. & Uji Ahli Isi Mata Kuliah & $96,40 \%$ & Sangat Baik \\
2. & Uji Ahli Desain Pembelajaran & $95,00 \%$ & Sangat Baik \\
3. & Uji Ahli Media E-learning & $96,50 \%$ & Sangat Baik \\
4 & Uji Ahli Video Pembelajaran & $98,00 \%$ & Sangat Baik \\
5 & Uji Coba Perorangan & $98,33 \%$ & Sangat Baik \\
\hline
\end{tabular}

Berdasarkan pengujian yang telah dilakukan oleh ahli isi mata kuliah Ahara yoga, dengan menggunakan metode pengumpulan data kuesioner dan instrumen yang digunakan yaitu lembar kuesioner. Didapatkan hasil perhitungan yang telah dikonversi pada tingkat pencapaian skala 5 , persentase pencapaian yaitu $96,40 \%$, sehingga mendapatkan kualifikasi sangat baik.

Pengujian yang telah dilakukan oleh ahli desain pembelajaran, dengan menggunakan metode pengumpulan data kuesioner dan instrumen yang digunakan yaitu 
lembar kuesioner. Didapatkan hasil perhitungan yang telah dikonversi pada tingkat pencapaian skala 5, persentase pencapaian yaitu 95\%, sehingga mendapatkan kualifikasi sangat baik.

Pengujian yang telah dilakukan oleh ahli media E-learning, dengan menggunakan metode pengumpulan data kuesioner dan instrumen yang digunakan yaitu lembar kuesioner. Didapatkan hasil perhitungan yang telah dikonversi pada tingkat pencapaian skala 5, persentase pencapaian yaitu 96,50\%, sehingga mendapatkan kualifikasi sangat baik. Berdasarkan pengujian yang telah dilakukan oleh ahli video pembelajaran, didapatkan hasil perhitungan yang telah dikonversi pada tingkat pencapaian skala 5, persentase pencapaian yaitu $96,40 \%$, sehingga mendapatkan kualifikasi sangat baik. Berdasarkan uji coba perorangan yang dilakukan oleh 3 (tiga) orang mahasiswa semester IV program studi Yoga Kesehatan di IHDN Denpasar diperoleh persentase tingkat pencapaian sebesar 98,33\% dengan kualifikasi sangat baik.

Dari perolehan hasil tersebut, maka dapat disimpukan bahwa pembelajaran blended dengan model flipped classroom layak untuk diterapkan dan tidak perlu direvisi. Berdasarkan masukan yang diberikan oleh ahli desain pembelajaran dan ahli media $E$ learning, masukan yang diberikan dipertimbangkan dan digunakan untuk menyempurnakan pembelajaran blended dengan model flipped classroom. Adapun revisi produk pembelajaran blended disajikan pada tabel 9.

Tabel 9. Perbaikan Produk Ahli Desain Pembelajaran

\begin{tabular}{cll}
\hline No & \multicolumn{1}{c}{ Komentar dan Saran } & \multicolumn{1}{c}{ Revisi } \\
\hline 1. & $\begin{array}{l}\text { Option evaluasi ada } 3 \text { dan ada 4, perlu } \\
\text { disamakan }\end{array}$ & Menyamakan option menjadi 4 \\
2. & $\begin{array}{l}\text { Tugas Lebih divariasikan lagi, dominan } \\
\text { hanya membuat ringkasan }\end{array}$ & Menvariasikan tugas \\
3. & Materi dalam bentuk cetak perlu di upload & $\begin{array}{l}\text { Meng-upload materi dalam bentuk } \\
\text { cetak_berupa handout }\end{array}$ \\
\hline
\end{tabular}

Berdasarkan masukan dan saran yang telah diberikan oleh ahli media pembelajaran (E-learning), maka perlu dilakukan perbaikan demi penyempurnaan produk yang dikembangkan. Adapun revisi produk E-learning disajikan pada tabel 4.

Tabel 10. Perbaikan Produk Ahli Media E-learnig

\begin{tabular}{lll}
\hline No & \multicolumn{1}{c}{ Komentar dan Saran } & \multicolumn{2}{c}{ Revisi } \\
\hline 1. & Perlu peningkatan kualitas sajian teks, pada \\
beranda mata kuliah, sehingga tidak nampak \\
seperti urutan teks yang monoton. Saran mengelola \\
teks pada aplikasi lain atau dengan sajian video di tampilan awal E-learning \\
beranda sehingga dari awal sudah terkesan $e-$ \\
learning ini menggunakan media pembelajaran \\
(video) yang menarik.
\end{tabular}

Adapun hasil pengembangan produk pembelajaran blended dengan model flipped classroom pada mata kuliah Ahara Yoga, disajikan gambar 1, 2, 3. 
Nida, Parmiti, Sukmana (2020)

Jurnal EDUTECH Universitas Pendidikan Ganesha. Vol. 8 No. (1) pp. 1-15 https://ejournal.undiksha.ac.id/index.php/JEU

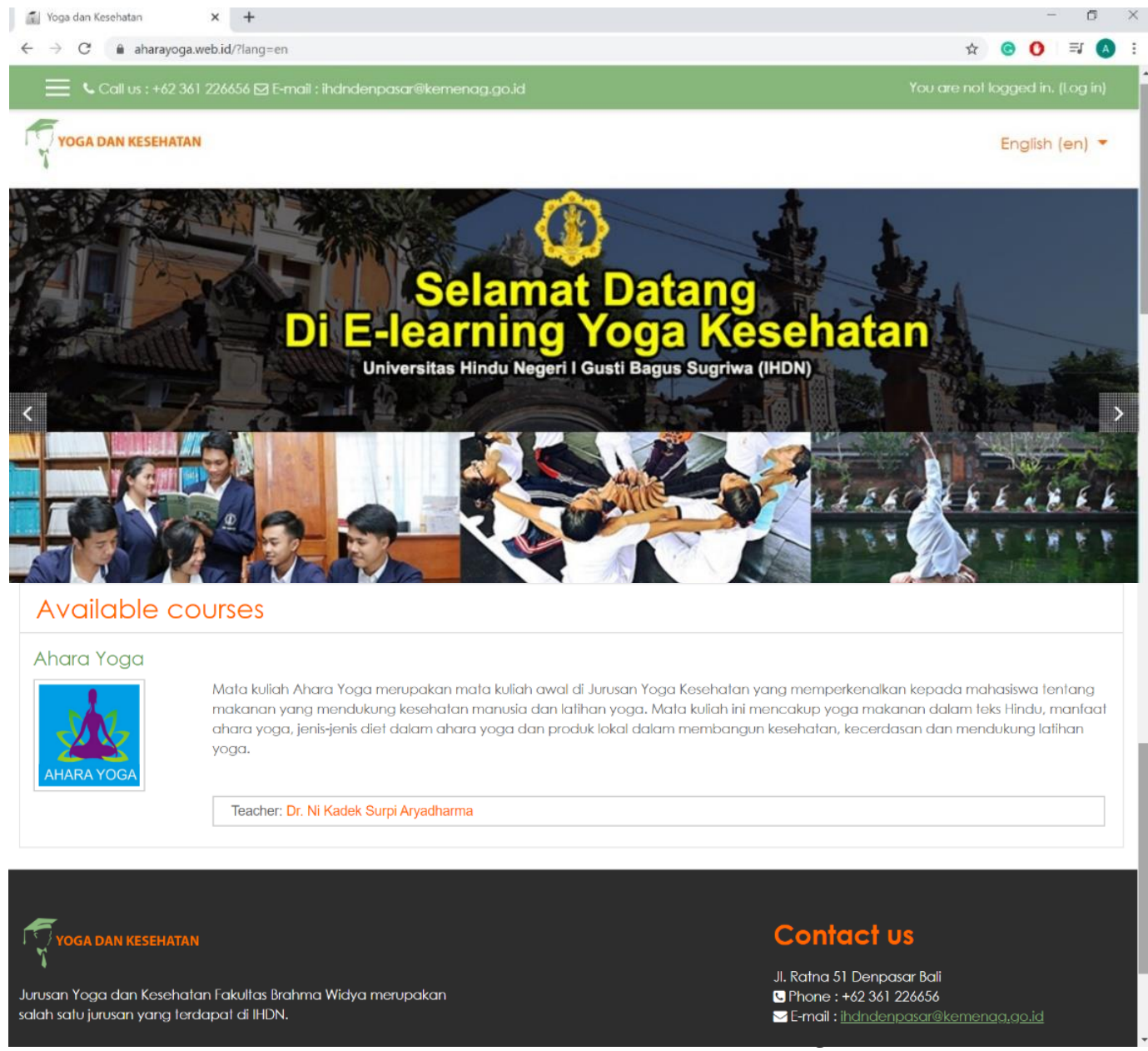

Gambar 1. Halaman Utama E-learning

\section{URAIAN MATERI}

Adik-adik mungkin bingung apa ifu Ahara Yoga dan Vegetarian yang akan dibahas dalam perkuliahan ini. Untuk memudahkan pemahaman adik-adik mengenai Ahara Yoga dan Vegetarian, marilah simak video pembelajaran Ahara Yoga dan Sejarah Vegetarian ini.

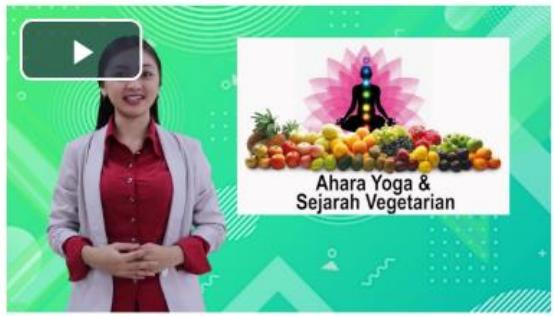

Apakah sudah jelas mengenai Ahara Yoga dan Vegetarian?

Jika masih bingung silahkan simak kembali video pembelajaran diatas, kemudian catat materi yang

tidak dipahami dan diskusikan dengan dosen serta rekan mahasiswa di kelas.

Gambar 2. Tampilan Uraian Materi dan Video Pembelajaran pada E-learning 


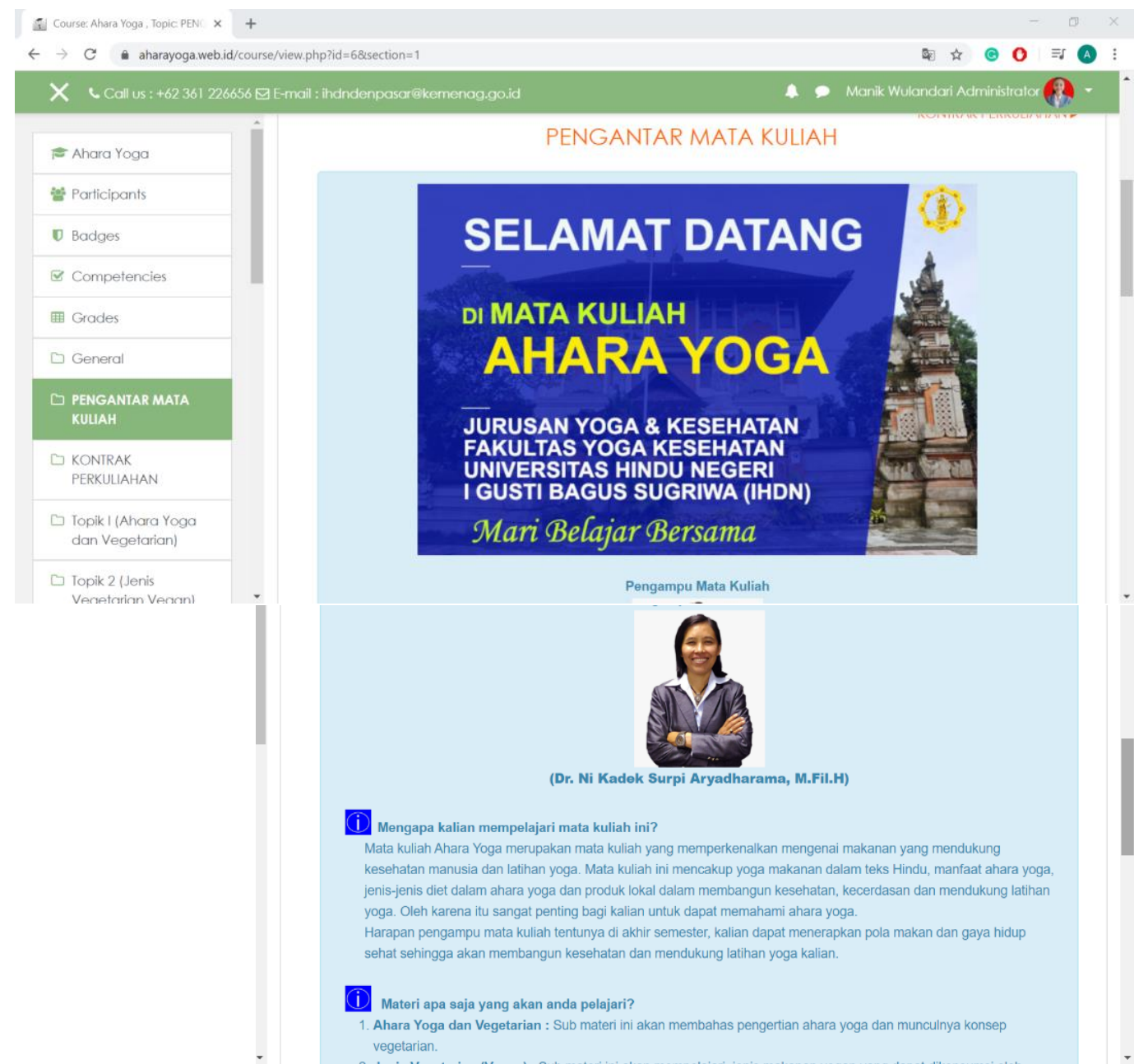

Gambar 3. Tampilan Pengantar Mata Kuliah pada E-learning

\section{PEMBAHASAN}

Berdasarkan uji validitas yang telah dilakukan, pembelajaran blended dengan model flipped classroom menunjukan hasil yang sangat baik dari para ahli dan layak untuk diterapkan. Hal ini dikarenakan, pengembangan pembelajaran blended melalui tahap analisis kebutuhan dan melalui proses pengembangan yang sistematis. Proses pengembangan pembelajaran blended berdasarkan model ADDIE sehingga berimplikasi pada keefektifan pembelajaran blended yang dimulai dari tahap analisis, perancangan, pengembangan hingga uji coba perorangan serta perbaikan untuk menunjang keberhasilan pengembangan pembelajaran blended, sehingga dapat digunakan dalam proses pembelajaran.

Berdasarkan penilaian yang telah diberikan oleh ahli mata kuliah terhadap produk pembelajaran blended berada pada kualifikasi sangat baik. Pada kuesioner, empat belas dari tujuh belas butir kuesioner memperoleh skor sangat baik, dan tiga butir mendapatkan skor baik. Kualifikasi sangat baik dapat tercapai disebabkan oleh beberapa hal yaitu: (1) penyusunan isi mata kuliah atau materi pada produk pembelajaran blended merujuk pada silabus, buku referensi yang relevan, dan telah melalui pertimbangan dosen pengampu mata kuliah tersebut; (2) isi mata kuliah memiliki kedalaman yang tercemin dari indikator pencapaian, capaian pembelajaran dan tujuan pembelajaran; (3) video pembelajaran sebagai bahan ajar yang terdapat pada E-learning mampu mewakili isi materi; (4) 
ketersedian dan kesesuaian tugas dan evaluasi dengan tujuan pembelajaran. Berkaitan dengan hal ini, Chaeruman (2017) menyatakan memetakan dan mengorganisasikan materi pembelajaran sangat penting sebagai upaya dalam, menentukan dan mengelompokkan materi pembelajaran kedalam pokok bahasan, sub pokok bahasan, dan pokok materi sesuai dengan capaian pembelajaran yang telah ditentukan. Berdasarkan pernyataan tersebut, Nampak jelas bahwa, pemetaan materi sangat penting untuk mengektifkan pembelajaran blended dengan model flipped classroom.

Penilaian yang telah diberikan oleh ahli desain pembelajaran berada pada kualifikasi sangat baik. Pada kuesioner, tiga belas dari tujuh belas butir kuesioner memperoleh skor sangat baik, dan empat butir mendapatkan skor baik. Kualifikasi sangat baik dapat tercapai dikarenakan beberapa hal yaitu (1) kejelasan identitas mata kuliah, rumusan indikator pembelajaran, capaian pembelajaran dan tujuan pembelajaran; (2) kesesuai isi materi dan keterpaduan materi, (3) ketersediaan evaluasi pembelajaran dalam pembelajaran blended. Berkaitan dengan hal ini, Chaeruman (2017) menyatakan bahwa capaian pembelajaran mata kuliah memiliki posisi yang sangat penting sebagai kunci pembuka dalam desain pembelajaran blended. Dari pernyataan tersebut, Nampak jelas bahwa capaian pembelajaran mata kuliah sangat penting karena menjadi acuan dalam menentukan unsur sistem pembelajaran blended, sehingga dapat memudahkan proses pembelajaran. Pengurutan capaian pembelajaran ini juga sangat penting karena akan menentukan langkah selanjutnya, yaitu mengorganisasikan materi, sehingga pemetaan dan pengorganisasian materi tidak didasarkan atas materi, tetapi didasarkan atas kompetensi.

Hasil review ahli media pembelajaran (E-learning) terhadap penilaian yang telah diberikan terhadap pengembangan produk pembelajaran blended berupa E-learning berada pada kualifikasi sangat baik. Pada kuesioner, empat belas dari tujuh belas butir kuesioner memperoleh skor sangat baik, dan tiga butir mendapatkan skor baik. Kualifikasi sangat baik dapat tercapai dikarenakan beberapa hal yaitu: (1) pengaturan layout ringkas dan sesuai dengan konten; (2) kemudahan akes situs E-learning dan kemudahan penggunaan E-learning, dan (3) E-learning mempermudah proses pembelajaran dan mampu meningkatkan serta memotivasi mahasiswa dalam belajar. Selajan dengan hal tersebut, hasil penelitian yang dilakukan oleh Irawan (2018) menyatakan dalam mengembangkan $E$ learning dengan memperhatikan pengaturan layout, dan kemudahan akses dapat memudahkan pembelajar dalam memahami konten dan mengaplikasikan E-learning. Darmawan (2014) juga menyatakan bahwa persyaratan penting dalam E-learning yaitu kemudahan dalam penggunaan E-learning, dan E-learning mampu memberikan suasana belajar yang nyaman dan aman. Hal ini senada dengan penelitian yang dilakukan oleh Nasuha (2015) menyatakan bahwa personalisasi E-learning memberikan kenyamanan lebih dalam pembelajaran. Berdasarkan hal tersebut, nampak jelas bahwa pengaturan $E$ learning baik dapat memotivasi mahasiswa dalam belajar.

Produk media pembelajaran lainnya yang dikembangkan adalah video pembelajaran. Uji validasi oleh ahli video pembelajaran berada pada kualifikasi sangat baik. Pada kuesioner, dua belas dari tiga belas butir kuesioner memperoleh skor sangat baik, dan satu butir mendapatkan skor baik. Kualifikasi sangat baik dapat tercapai dikarenakan beberapa hal yaitu (1) kemenarikan media video; (2) materi yang disajikan dalam video sesuai dengan pembelajaran, dan (3) presenter lugas dan mampu meyakinkan mahasiswa saat menyampaikan informasi. Hal tersebut senada dengan penelitian yang dilakukan oleh Agustien, dkk (2018) menyatakan bahwa video pembelajaran yang menarik, menyajikan gambar dan bersuara sangat efektif memvisualisasikan materi sehingga siswa dapat memahami konten yang terdapat pada video pembelajaran. Penelitian yang dilakukan oleh Tegeh, ddk (2019) menyatakan bahwa yang menarik dapat menarik perhatian siswa dalam 
belajar, sehingga dapat meningkatkan hasil belajar. Berdasarkan penilaian tersebut maka dapat disimpulkan bahwa, video pembelajaran yang telah dikembangkan layak digunakan untuk membantu mahasiswa dalam belajar pada Mata Kuliah Ahara Yoga.

Pembelajaran blended bertujuan untuk membantu peserta didik berkembang dan memberikan peluang praktis dalam belajar secara mandiri. Pembelajaran blended memberi kesempatan untuk mengintegrasikan kemajuan teknologi dalam pembelajaran. Model flipped classroom memiliki kelebihan seperti pembelajar akan mengambil tanggung jawab untuk belajar, konsistensi belajar dengan pengulangan untuk mencegah siswa tertinggal di kelas (Ozdamli, dkk, 2016) Model flipped classroom dapat meningkatkan keaktifan pelajar dan merasa lebih nyaman dan terbuka saat berinteraksi (Adhitiya, dkk, 2015).

Berdasarkan hasil review pembelajaran blended dari uji coba perorangan, mendapatkan kualifikasi sangat baik. Kriteria uji perorangan yaitu tersedianya media pembelajaran pendukung proses pembelajaran yang terdapat pada perangkat pembelalajaran blended mendapatkan skor sangat baik dari ketiga responden. Hal tersebut dikarenakan media yang digunakan melalui pertimbingan dalam memilih media yang baik seperti komposisi warna, gambar, dan tulisan sehingga akan terlihat jelas dan menarik. Selain itu, ketepatan pemilihan bahan ajar yaitu video pembelajaran dan E-handout, merupakan faktor pendukung keberhasilan dalam mengembangkan pembelajaran blended dengan model flipped classroom. Smaldio (dalam Chaeruman, 2017) juga menyatakan bahwa pemilihan dan penentuan asset digital, untuk ragam pengetahuan konsep, yang paling baik adalah media video. Pengembangan pembelajaran blended dikembangkan berdasarkan hasil analisis karakteristik mahasiswa, dan analisis mata kuliah. Kriteria lainnya yaitu pembelajaran online dapat melengkapi pembelajaran tatap muka, juga mendapatkan skor sangat baik dari ketiga responden. Hal tersebut karena dalam pembelajaran online telah tersedia bahan ajar mandiri yang dapat digunakan oleh mahasiswa kapan saja dan dimana saja. Hal tersebut disesuaikan dengan kategorisasi pembelajaran blended menurut Allen dann Seaman pada tabel 3.

Tabel 3. Continuum for Instructional Model

\begin{tabular}{|c|c|c|}
\hline $\begin{array}{c}\text { Proporsi Konten } \\
\text { Pembelajaran } \\
\text { online }\end{array}$ & $\begin{array}{c}\text { Tipe } \\
\text { Pembelajaran }\end{array}$ & Deskripsi Tipe Pembelajaran \\
\hline $0 \%$ & Tradisional & 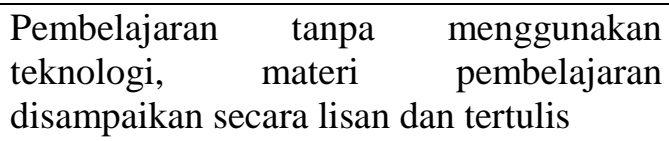 \\
\hline $1-29 \%$ & Web Facilitated & $\begin{array}{l}\text { Pembelajaran yang menggunakan fasilitas } \\
\text { web untuk menfasilitasi pembelajaran } \\
\text { tatap muka. Dapat menggunakan sistem } \\
\text { manajemen khusus (CMS) untuk } \\
\text { memposting silabus dan tugas. }\end{array}$ \\
\hline $30-79 \%$ & Blended/Hybrid & $\begin{array}{l}\text { Pembelajaran yang memadukan tatap } \\
\text { muka dan online. Proporsi pembelajaran } \\
\text { online biasanya menggunakan diskusi } \\
\text { online dan mengurangi jumlah pertemuan } \\
\text { pembelajaran secara tatap muka. }\end{array}$ \\
\hline $80+$ & Online & $\begin{array}{l}\text { Pembelajaran yang biasanya dilakukan } \\
\text { secara online dan tidak memiliki } \\
\text { pertemuan tatap muka. }\end{array}$ \\
\hline
\end{tabular}

(Sumber: Allen and Seaman, 2016:7) 
Berdasarkan tabel diatas, maka dapat disimpulkan bahwa pembelajaran dapat disebut sebagai pembelajaran blended jika proporsi penggunaan E-learning yaitu 30-79\% dan digabungkan dengan pembelajaran tatap muka.

\section{SIMPULAN DAN SARAN}

Simpulan dari penelitian ini yaitu pengembangan pembelajaran blended dengan model flipped classroom pada mata kuliah Ahara Yoga mendapatkan kualifikasi sangat baik dan layak untuk diterapkan dalam proses pembelajaran. Diharapkan mahasiswa lebih termotivasi dalam belajar. Dosen diharapkan termotivasi mengembangkan media pembelajaran yang kreatif untuk menunjang proses pembelajaran.

\section{DAFTAR PUSTAKA}

Adhitiya, dkk. (2015). Studi Komparasi Model Pembelajaran Tradisional Flip Classroom dengan Peer Instruction Flipped Terhadap Kemampuan Pemecahan Masalah. Journal of Mathematics Education, 4(2), 116-126.

Agung, A. A. G. (2017). Metodologi Penelitian Kuantitatif (Perspektif Manajemen Pendidikan). Singaraja: Universitas Pendidikan Ganesha.

Agustien, dkk. (2018). Video merupakan suatu media yang sangat efektif untuk membantu proses pembelajaran. Video kaya akan informasi dan tuntas karena sampai kehadapan peserta didik secara langsung [6]. Video menambah dimensi baru terhadap pembelajaran sejarah. Sebab video dapa. Jurnal Edukasi, 5(1), 19-23.

Albiladi dan Khlood. (2019). Blended Learning in English Teaching and Learning: A Review of the Current Literature. Journal of Language Teaching and Research, $10(2), 232-238$.

Allen and Seaman. (2016). Online Report Card Tracking Online Education in the United States. USA: Survey Research Goup.

Ceylan, A. (2017). Effect of Blended Learning to Academic Achievement. Journal of Human Sciences, 14(1), 308-320.

Chaeruman, U. (2017). Pedati Model Desain Sistem Pembelajaran Blended. Jakarta: Ristekdikti.

Darmawan, dkk. (2014). Pengembangan E-learning Teori dan Desain. Bandung: Remaja Rosakarya.

Dziuban, dkk. (2018). Blended Learning: The New Normal and Emerging Technologies. International Journal of Educational Technology in Higher Education, 15(3), 1-16.

Harahap, dkk. (2019). The Effect of Blended Learning on Student's Learning Achievement and Science Process Skills in Plant issue Culture Course. International Journal of Instruction, 12(1), 521-538.

Irawan, H. (2018). Keefektifan E-Learning Sebagai Media Pembelajaran (Studi Evaluasi Model Pembelajaran E-Learning Smk Telkom Sandhy Putra Purwokerto). Jurnal Inovasi Teknologi Pendidikan, 5(1), 1-11.

Kalantarrashidi, dkk. (2015). Effect of Blended Learning Classroon Environment on Student's Satisfaction. Journal of Educaion and Training Studies, 3(5), 225-230.

Kazakoff, dkk. (2017). Efficacy of a blended learning approach to elementary school reading instruction for students who are English Learners. Education Tech Rearch 
Development, 66(2), 429-449.

Kurniawati, dkk. (2019). Penerapan Blended Learning Menggunakan Model Flipped Classroom Berbantuan Google Classroom Dalam Pembelajaran Matematika SMP. Jurnal Pendidikan Matematika, 7(1), 8-19.

Mahadewi, dkk. (2012). Buku Ajar: Media Video Pembelajaran (E-Book). Singaraja: Undiksha.

Nasuha. (2015). Pengembangan Personalisasi Gaya Belajar pada E-learning dengan Menggunakan Felder Silverman Learning Style Model untuk Sekolah Menengah Kejuruan (SMK). Jurnal Nasional Pendidikan Teknik Informatika (Janapati), 4(2), $39-44$.

Oktaria, dkk. (2018). Model Blended Learning Berbasis Moodle. Jakarta: Halaman Moeka Publishing.

Ozdamli, dkk. (2016). Flipped Classroom Approach. Journal on Educational Technology, $8(2), 98-105$.

Prawiladilaga, D. S. (2015). Prinsip Desain Pembelajaran (Instructional Design Principles). Jakarta: Prenadamedia Group.

Putra, dkk. (2017). Pengaruh Penggunaan Media Pembelajaran Berbasis Aplikasi Android terhadap Hasil Belajar Siswa. Jurnal Inovasi Pendidikan Kimia, 11(2), 2009-2018.

Retnawati, H. (2016). Analisis Kuantitatif Instrumen Penelitian (Panduan Peneliti, Mahasiswa, dan Psikometrian). Yogyakarta: Parama Publishing.

Richey, dkk. (2015). Developmental Research: Studies of Instructional Design and Development. Jounal od Educational Research. 3(4), 460-466.

Surpi, N. K. (2017). Hadapi Tantangan Global, Lembaga Pendidikan Hindu Harus Jadi Gurukula Modern. Jurnal Penjamin Mutu, 3(2), 171-179.

Tegeh, dkk. (2019). Pengembangan Media Video Pembelajaran Dengan Model Pengembangan 4d Pada Mata Pelajaran Agama Hindu. Jurnal Mimbar Ilmu, 24(2), $158-166$.

Tegeh dan Jampel. (2017). Metode Penelitian Pengembangan. Singaraja: Universitas Pendidikan Ganesha. 